\title{
Relationship between accounting information systems implementation and corporate governance of rural banks in Indonesia
}

\author{
Rima Rachmawati ${ }^{1}$ \\ ${ }^{1}$ Economics Faculty, Widyatama University, Indonesia
}

\begin{abstract}
The purpose of this paper is to examine the relationship between accounting information systems implementation and the governance of rural banks (bank perkreditan rakyat/BPR). Specifically, this study examines the effect of bookkeeping systems, financial reporting, budgeting systems, and IFRS for SMEs implementation on good corporate governance of rural banks. PLS-SEM was employed for data analysis to 145 rural banks registered in Regional Owned Bank Association of Central Java Indonesia. The results of data analysis found that bookkeeping systems, financial reporting and budgeting systems implemetation positively affect good corporate governance of rural banks, while IFRS for SMEs implementation was not significantly affect good corporate governance of rural banks.
\end{abstract}

\section{Keywords}

accounting information systems implementation; bookkeeping systems; financial reporting; budgeting system; IFRS for SMEs; good corporate governance; rural banks

\section{INTRODUCTION}

Rural banks (bank perkreditan rakyat/BPR) in Indonesia has been experiencing the growth of loan portfolio and third party funds in recent years (https://ekonomi.kompas.com, n.d). However in another side some of them also shut down their business since corporate governance issues; $84.13 \%$ due to fraud cases, $9.52 \%$ due to self-liquidation; and $6.39 \%$ were mismanaged (www.solo.tribunnewes.com, n.d). Some of rural banks were closed by The Financial Services Authority (Otoritas Jasa Keuangan/OJK) since they have not applied the precautionary principle in managing their business, especially in the credit sector, reflected in the high NPL of $45 \%$ which has an impact on the need for this loss reserve fund, and resulted in a negative Capital Adequacy Ratio (CAR).

Those issues indicate the existence of accounting and audit failures that caused the failure of the rural banks. Eventually, it will bring to the lost of trust from community, customers, investors. To overcome the problems faced by rural banks, OJK had issued regulation about the implemention of corporate governance for rural banks (Peraturan Nomor 4/POJK.03/2015 Tentang Penerapan Tata Kelola Bagi Bank Perkreditan Rakyat, n.d.). Its objective was to protect stakeholders fo rural banks and furthermore increase public confidence in banks.

Accounting information systems play an important role in realizing good corporate governance in organizations because the accounting information system produces the main financial reports that will be used by stakeholders (Christopher, Guay, Joseph, Link, \& Armstrong, 2010). Stakeholders will use the main financial statements for decision making, thus the quality and reliability of the information presented in the financial statements is very important for stakeholders (Corcoles, Penalver, \& Ponce, 2011). Accounting information systems that function properly in accordance with business processes and generally accepted accounting standards tend to increase the level of corporate governance in organizations, build a better business world, increase investor confidence (International Finance Corporation, 2017). 
Accounting will show ways to continue corporate governance where poor governance generally comes from financial dissatisfaction (Shil, 2008). Research that links accounting with corporate governance has been carried out by Haniffa \& Cooke (2002) and Eng \& Mak (2003). Therefore the objective of this study is to examine whether the implementation of accounting information systems can improve the corporate governance of rural banks in Indonesia. Particularly, this paper examine the effect of bookkeeping systems, financial reporting, budgeting systems, and IFRS for SMEs implementation on good corporate governance of rural banks in Indonesia.

\section{LITERATURE REVIEW AND HYPOTHESES DEVELOPMENT}

\section{Bookkeeping system and corporate governance}

Bookkeeping is the recording of financial transactions in an entity. There are two bookkeeping events, namely single bookkeeping and paired bookkeeping. Paired bookkeeping requires that transactions are always recorded by debiting and crediting two or more accounts with the same amount. It plays an important role in producing accurate financial reports. Accurately means that the financial statements contain information that is free of misstatement, the error can be started since the bookkeeping was carried out, therefore the bookkeeping system affects the presentation of financial statements that contain elements of transparency which is a philosophy of good corporate governance. According to (Nobes \& Stadler, 2013) the everyday work of accountants involves recording transactions in the classification systems that is double entry bookkeeping.

Bookkeeping system consists of indicators; have a policy/ procedure for recording transaction, verify the transaction by other people, transaction document is signed by the author and recipient of the document, procedure for using an account to record transactions.

H1: Bookkeeping systems positively affect good corporate governance.

\section{Financial reporting and corporate governance}

Financial reporting not only presents financial information but also non-financial information. In recent years the need for non-financial information presentation is more in demand. However, this does not mean that financial information is no longer in demand. The financial statements are required to be made to meet the interests of investors, creditors, the government and the financial statements are made as a form of accountability principle to the agent. The financial statements consist of financial position statements, income statements, changes in equity statements, cash flow statements and notes to financial statements (Martani, 2017). The financial statements of rural banks following IFRS SME's guidelines consist of: balance sheet, income statement, statement of changes in equity, cash flow statement and notes to financial statements.

The Board of Directors is responsible for the reliability of the financial statements, the reliability of financial statements is influenced by the people involved in preparing and monitoring reports, such as: auditors, corporate supremacy, Capital Market and Financial Institution Supervisory Agency (Bapepam = called in Indonesia), lawsuits.

The company is a place where wealth is collected and control is needed by managers, characterized by the separation of control over capital from capital ownership (Bushman \& Smith, 2003). Corporate governance generally focuses on understanding mechanisms designed to reduce agency problems. And, directors have an obligation to provide correct information about finances to investors (Pallisserry, 2016).

Financial reporting consists of indicators; additional financial reports are prepared in the Rural Bank, financial statements are analyzed, financial statement information in evaluating performance.

H2: Financial reporting positively affect good corporate governance.

\section{IFRS for SMEs and corporate governance}

Financial accounting standards are a framework in the procedures for making financial statements so that uniformity in the presentation of financial statements so that financial statements are made 
understandable, reliable, can be compared by stakeholders (http://www.simulasikredit.com, n.d.), (BPR, 2010). Financial accounting standards are made by harmonizing with international standards. Financial accounting standards that have been harmonized with International Financial Reporting Standars (IFRS) (Alp \& Ustundag, 2009) differences have been minimized by IFRS by the Indonesian Board of Accountants' Standards Board because of Indonesia's commitment as a member of the G20 in the Southeast Asia region (IAI, 2016). The financial statements that have been made in accordance with IFRS for SMEs are expected to be accepted globally and this is important for stakeholders.

The literature states that the benefits of using accounting standards can improve in financial reporting and auditing (Joshi \& Ramadhan, 2002). This advantage is closely related to corporate governance mechanisms, and is expected to contribute to good governance practices (Uyar \& Güngörmüş, 2013). This research was conducted at the credit bank so that the accounting standards used were IFRS for SMEs, in accordance with Bank Indonesia regulations. (BPR, 2010).

Financial reporting consists of indicators transaction are recorded in accordance with financial accounting standars, the financial statement are prepared in accordance with financial accounting standards.

H3: IFRS for SMEs positively affect good corporate governance.

\section{Budgeting System}

External auditors are parties that play a role in the suitability of financial statements, through management accounting is carried out controlling the company and producing management accounting information to accept those who are supported and implement corporate governance (Seal, 2006). A good corporate governance structure is the driving force for adopting appropriate management accounting techniques in business while on the other hand management accounting produces quality information needed for decision making (Huynh, 2015).

Budgeting is one of the management tools used to control the operational implementation of the organization (Uyar \& Kuzey, 2016) and estimating future economic conditions, including costs, interest rates, demand for products, and the level of settlement thus budgeting increases management awareness of the company's external environment (Mwangi, 2011). Budgeting is needed as a target that will limit managers in issuing costs, then budgeting will be used as a check-and-control tool, this is the reason that budgeting is the basis of corporate governance, management accounting is implement well can have an impact on good corporate governance (Mwangi, 2011).

Budgeting system consists of indicators there is a separate unit on budgeting to enable better, planning and control in the company, the operating budget is regulary arranged and revised if necessary, operational budgets are used in managerial decision making.

H4: Budgeting systems positively affect good corporate governance.

\section{METHODS}

This study uses a verification approach aimed at finding out how far independent factors influence a variable with the aim of testing the hypotheses. Primary data used in this study in the form of a questionnaire with respondents part of the accounting information system users.

Verification analysis was carried out using the Structural Equation Modeling method with the least square (PLS-SEM) approach. PLSSEM model includes the outer model and inner model. To test the validity and reliability of the instruments, this study employed discriminant validity, internal consistency, and individual items are used for analysis of measurement models (Hair, Hult, Ringle, \& Sarstedt, 2014a). The average variance extracted (AVE), the composite reliability $(\mathrm{CR})$ and the Pearson correlation a coefficient with the square root of AVE value.

The threshold value of $C R$ is suggested 0.7 (Nunnally, 1978 in (Uyar, 2017)). Alpha Cronbach's construct value ranges from 0.779 to 0.929 which is far above the recommended value of 0.7 . Likewise with the $\mathrm{CR}$ value of all constructs above 0.7. AVE value (Fornell \& Larcker, 1981), MSV and ASV (Hair et al., 2014a). AVE with a threshold of 0.5 fulfilled for all constructs. MSV and ASV values must be lower than Ave values for each construct, the results of 
Table 1.

Correlation Coefficients and Reliability Analysis Results

\begin{tabular}{cccccccccccccc}
\hline Constructs & AVE & CR & A & MSV & ASV & $\mathbf{1}$ & $\mathbf{2}$ & $\mathbf{3}$ & $\mathbf{4}$ & $\mathbf{5}$ & $\mathbf{6}$ & $\mathbf{7}$ & $\mathbf{8}$ \\
\hline BKS & 0,621 & 0,860 & 0,779 & 0,38 & 0,15 & 1,00 & & & & & & & \\
FR & 0,755 & 0,900 & 0,823 & 0,42 & 0,18 & 0,66 & 1,00 & & & & & \\
IFRS & 0,984 & 0,992 & 0,983 & 0,19 & 0,08 & 0,34 & 0,31 & 1,00 & & & & \\
BS & 0,633 & 0,837 & 0,719 & 0,32 & 0,15 & 0,65 & 0,72 & 0,44 & 1,00 & & & \\
CGL & 0,472 & 0,937 & 0,929 & 0,29 & 0,14 & 0,79 & 0,75 & 0,40 & 0,74 & 1,00 & & & \\
OY & 1,000 & 1,000 & 1,000 & 0,53 & 0,14 & $-0,02$ & $-0,01$ & $-0,05$ & $-0,07$ & $-0,01$ & 1,00 & & \\
RVN & 1,000 & 1,000 & 1,000 & 0,53 & 0,15 & $-0,07$ & 0,02 & $-0,05$ & $-0,09$ & $-0,02$ & 0,73 & 1,00 & \\
NSTFF & 1,000 & 1,000 & 1,000 & 0,50 & 0,13 & $-0,02$ & 0,03 & $-0,05$ & $-0,01$ & 0,00 & 0,65 & 0,71 & 1,00 \\
\hline
\end{tabular}

Notes: BKS: Bookkeeping system; FR: Efficacy of Financial reporting; IFRS for SMEs: Adoption of Accounting Standards; BS: Efficacy of the Budgeting System; CGL: Corporate Governance Level; OY: Number of operating years; RVN: Revenue; NSTFF: Number of staff members; CR: Composite reliability, a Cronbach's Alpha, MSV: maximum-shared variance, ASV: average shared variance, AVE: average variance extracted;

data processing all constructs meet these requirements.

Model evaluation is divided into outer model and inner model. Outer model to ensure data has quality reliability and validity. The validity of the data uses a significant factor loading value. Data reliability uses R2 with R2 not less than 0.5 (Bollen, 1989)..

Evaluation of the inner model or also called structural model testing begins by testing collinearity assessment and structural model path coefficients. Collinearity uses a tolerance value (VIF) with a value that must be lower than 5 . The path coefficients have a standard value between -1 and +1 , the approximate path coefficient approaching +1 represents a strong positive relationship (preferably a negative value) that is statistically significant (different from 0 in the population) (Bollen, 1989).

\section{RESULTS AND DISCUSSION}

The target population in this study is rural banks that are registered in the Association of Indonesian Rural Banks (Perbarindo = called in Indonesia). The sample determination technique uses simple random sampling with the determination of the minimum sample size using power analysis, at a significance level of $5 \%-10 \%$ the number of directions of the largest arrow pointing towards the construct is 4 and statistical power is 0.8 and is expected to produce a minimum $\mathrm{R}^{2}$ of 0.25 , then the minimum sample size required is 65 samples (Hair et al., 2014a).

The factor loading value based on PLS, factor loading all items of the questionnaire statement have met the standard, except for one statement and have been issued in the model.. There are five factors and three control variables (operating years-OY, revenue-RVN, and number of staff-NSTFF).

The latent variable is the effectiveness of the accounting information system (with four sub-dimensions; bookkeeping systems (BKS), efficacy of financial reporting (FR), IFRS for SME's (IFRS), efficacy of budgeting systems (BS)) and corporate governance level (CGL). While the size of the company is measured by; the amount of income and number of staff members is expected to influence corporate governance because larger companies tend to have a greater amount of resources to commit to the formation of a better corporate governance structure. On the other hand, the company's operational age is assumed to have an impact on the corporate governance structure.

Reliability and variability of a variable are assessed using Confirmatory Factor Analysis (CFA). Based on the data collected, the maximum likelihood method will be processed. All the results of the validity and reliability tests indicate that the research does not indicate a problem of discriminant validity.

SEM with the Partial Least Squares (PLS) approach was applied to test hypothesized relationships. Table 2 shows the results of Structural Equation Modeling (SEM) that found evidence of bookkeeping systems influences the improvement of Rural Bank governance at a $10 \%$ significance level, financial reporting affects the improvement of Rural governance Banks at a significance level of $5 \%$, and budgeting systems affect the improvement of Rural Bank governance at a $1 \%$ significance level. As well as no evidence of the relationship between IFRS for SMEs in improving the governance of Rural Bank in Central Java.

Based on the results of the inner model test with the calculation of the values of 


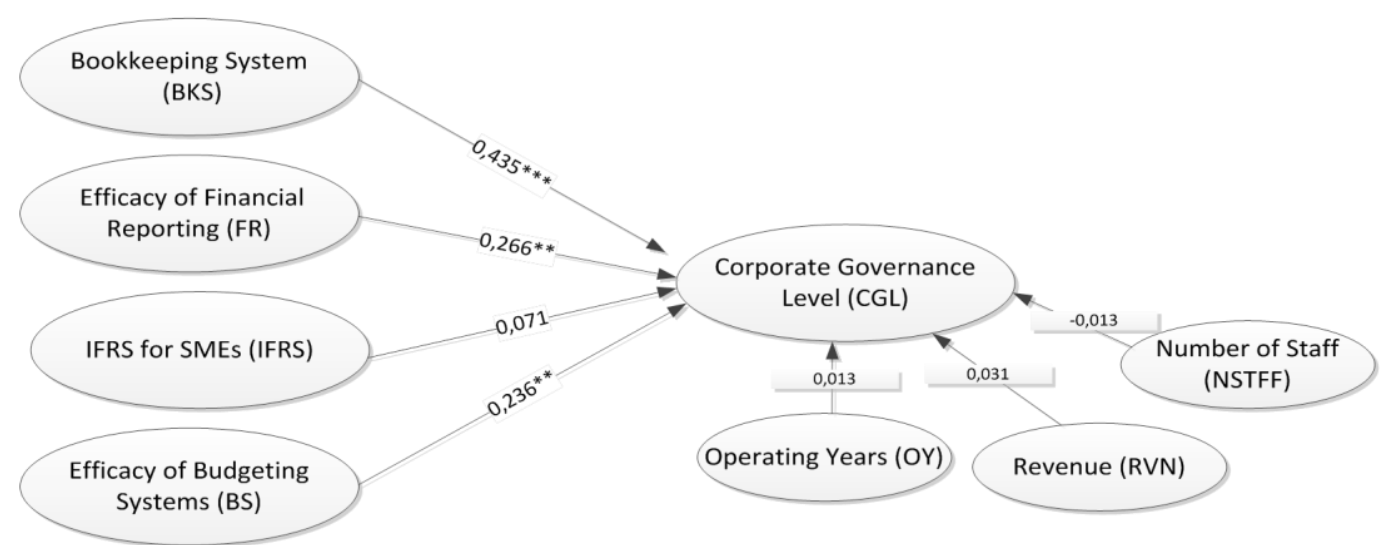

Notes: $* \mathrm{p}<.10 ; * * \mathrm{p}<.05 ; * * * \mathrm{p}<.01$. BKS: Bookkeeping system; FR: Efficacy of Financial reporting; IFRS for SMEs: Adoption of Accounting Standards; BS: Efficacy of the Budgeting System; CGL: Corporate Governance Level; OY: Number of operating years; RVN: Revenue; NSTFF: Number of staff members

Figure 2.

\section{Path Coefficients}

coefficients and t-statistics, hypothesis 1 was supported with a significance level of $1 \%$, the value of coefficients is 0.435 and t-statistics 3.234. This means that bookkeeping has an effect on the realization of corporate governance. The result also support hypothesis 2 with a significance level of $5 \%$, the value of coefficients is 0.266 and $t-$ statistics is 1.182 . This means that financial reporting has an effect on the realization of corporate governance.

Hypothesis 4 which predict that budgeting system has positive effect on good corporate governance is supported with a significance level of $5 \%$, the value of coefficients is 0.236 and t-statistics is 2.046. However, hypothesis 3 is not supported with a significance level of $5 \%$, the value of the coefficients is 0.071 and t-statistics is 1.482. This means that IFRS does not affect the realization of corporate governance.

Variability in improving rural banks governance is built by the variability of bookkeeping system by $43.5 \%$; financial reporting of $26.6 \%$ and budgeting systems $23.6 \%$. The control variable for this study is the length of Rural Bank operations and revenue. While the control variable number of staff is not able to control the relationship of accounting information systems to improving the governance of Rural Banks.

Chin (2016) in Uyar \& Kuzey (2016) recommended evaluating predictive relevance and predictive power (see Table 3). According to Chin, 2016 in (Uyar \& Kuzey, 2016) threshold value for $R^{2}$; substantial (0.67), medium (0.33) and weak (0.19). Based on $R^{2}$ result of 0.744 or $74.4 \%$ interpreted as a variability of corporate governance approved by the variability of accounting information systems of $74.4 \%$. The value of $\mathrm{R}^{2} 74.4 \%$ according to (Hair, Hult, Ringle, \& Sarstedt, 2014b) included in the substantial category. The definition of an

Table 2

Structural Equation Modeling Results

\begin{tabular}{|c|c|c|c|c|c|}
\hline \multicolumn{3}{|c|}{ Hypothesized Relationships } & \multirow{2}{*}{$\begin{array}{c}\text { Coefficients } \\
0,435\end{array}$} & \multirow{2}{*}{$\frac{\text { t-statistics }}{3,234}$} & \multirow{2}{*}{$\begin{array}{l}\text { Results } \\
\text { Supported }\end{array}$} \\
\hline $\mathrm{H} 1$ & BKS & CGL & & & \\
\hline $\mathrm{H} 2$ & FR & CGL & 0,266 & 2,182 & Supported \\
\hline H3 & IFRS for SMEs & CGL & 0,071 & 1,482 & Not supported \\
\hline $\mathrm{H} 4$ & BS & CGL & 0,236 & 2,046 & Supported \\
\hline Cont. Var & OY & CGL & 0,013 & 0,192 & \\
\hline Cont. Var & RVN & CGL & 0,031 & 0,392 & \\
\hline Cont. Var & NSTFF & CGL & $-0,013$ & 0,185 & \\
\hline
\end{tabular}


Table 3.

The Explained Variance and Predictive Relevance Values of the Corporate Governance Level

\begin{tabular}{lllll}
\hline Total & SSO & SSE & $\mathbf{Q}^{2}$ & $\mathbf{R}^{\mathbf{2}}$ \\
\hline CGL & 2465,0 & 1680,7 & 0,318 & 0,744 \\
GoF & 0,775 & & & \\
\hline Notes: SSO: Sum of the Squared Observation; SSE: Sum of the squared prediction errors. \\
GoF $=\boldsymbol{F} \overline{\mathrm{Co}} \times \overline{\mathrm{R}^{2}}$
\end{tabular}

Table 4.

Effect sizes of the Corporate Governance Level

\begin{tabular}{lllllll}
\hline $\begin{array}{l}\text { Predecessor Latent } \\
\text { Variables }\end{array}$ & $\begin{array}{l}\mathbf{R}^{\mathbf{2}} \\
\text { Included }\end{array}$ & $\begin{array}{l}\mathbf{R}^{\mathbf{2}} \\
\text { excluded }\end{array}$ & $\mathbf{f}^{\mathbf{2}}$ & $\begin{array}{l}\mathbf{Q}^{\mathbf{2}} \\
\text { included }\end{array}$ & $\begin{array}{l}\mathbf{Q}^{\mathbf{2}} \\
\text { excluded }\end{array}$ & $\mathbf{q}^{\mathbf{2}}$ \\
\hline BKS & 0,744 & 0,659 & 0,114 & 0,318 & 0,302 & 0,052 \\
FR & 0,744 & 0,718 & 0,035 & 0,318 & 0,306 & 0,037 \\
IFRS for SME & 0,744 & 0,741 & 0,004 & 0,318 & 0,317 & 0,005 \\
BS & 0,744 & 0,730 & 0,019 & 0,318 & 0,306 & 0,039 \\
OY & 0,744 & 0,744 & 0,000 & 0,318 & 0,318 & 0,000 \\
RVN & 0,744 & 0,744 & 0,000 & 0,318 & 0,318 & 0,000 \\
NSTFF & 0,744 & 0,744 & 0,000 & 0,318 & 0,318 & 0,000 \\
\hline
\end{tabular}
Efficacy of the Budgeting System; CGL: Corporate Governance Level; OY: Number of operating years; RVN: Revenue; NSTFF: Number of staff members;

accounting information system provides important meaning in the regulation of corporate governance.

In addition to explanatory power, the $\mathrm{Q}^{2}$ test was used to assess the relevance of the model predictions to fit. This is used to measure the success of the reconstruction of the observed values of the model. A positive value of $Q^{2}\left(Q^{2}>0\right)$ indicates that the model has predictive relevance and vice versa if $Q^{2}$ $<0)$ indicates that the model has no predictive relevance.

The predictive relevance of the level of corporate governance is positive $31.8 \%$ indicating that the endogenous latent variable of the proposed model has positive relevance. GoF was developed by (Tenenhaus, Amato, \& Vinzi, 2004) used to determine the overall predictive performance of the model, calculated by the geometric mean of the average communality index and the average $R^{2}$ value. The GoF value is $77.5 \%$ which indicates that the model takes $77.5 \%$ of the fit that can be calculated.

The effect size of $f^{2}$, as well as the size of the effect of $\mathrm{q}^{2}$ is related to the explained variance $\left(R^{2}\right)$ with predictive relevance $\left(Q^{2}\right)$ respectively. The value $\mathrm{f} 2$ shows how far the latent variable has a predictive value (effect size) in generating $R^{2}$ for the dependent variable. Likewise, the value of $q^{2}$ shows how far the latent variable has predictive relevance (effect size) in generating $Q^{2}$ for the dependent variable. Effect size is a measure to determine the effect of a particular predictor construct on endogenous latent variables. (Hair et al., 2014a) made a category: small (0.02-0.14); moderate (0.150.34 ) and large (above 0.35). Table 4 shows the effect sizes of $\mathrm{f} 2$ and $\mathrm{q} 2$ where the endogenous variable is the level of corporate governance.

Corporate governance consists of indicators plans shared with employees, employees knows the organization's goals, job description employee rights and responsibilities are written, every meeting is planned, everyone's performance is quite assessed, employee selection is based on job requirements, each person's performance is assessed according to clearly defined and written regulations.

Based on the results of data analysis, all have a small size effect in generating predictive relevance $\left(Q^{2}\right)$ for the level of corporate governance.

In line with previous research that the bookkeeping system, IFRS, the budgeting system affects governance in BPRs while the budgeting system has no effect on BPR governance (Uyar, 2017).

\section{CONCLUSION}

The empirical test results show that the independent variables influence BPR 
governance. The independent variable in this study is accounting information system consisting of bookkeeping system, efficacy of financial reporting, IFRS for SMEs and efficacy of the budgeting system.

Bookkeeping system practice, the practice of preparing financial reporting and guidelines for financial report preparation, namely IFRS for SMEs in BRP, found evidence that these variables had an effect on the realization of BPR governance. whereas the budgeting system practice found no evidence that could influence the realization of BRP governance.

The results of this study provide recommendations for stakeholders in BPR to reorganize governance practices. In the governance assessment, recommendations can be given to redesign indicators of governance assessment.

The results of this study have been implications for board members, managers, and organizations. One of the responsibilities of board members is to establish corporate governance and resolve agency issues. When designing a corporate governance mechanism, it is designed as a well designed accounting information system.

Rural research and development systems, financial reporting and budgeting systems can affect the level of governance in rural banks in Central Java.

It means that through the implementation of bookkeeping, the financial statements and budget arrangements can help the implementation of the Rural Bank's governance.

Bookkeeping carries out recording and reporting financial transactions accurately and transparently, thus helping management comply with laws and regulations.

In line with previous research (Uyar, 2017). That bookkeeping systems, financial reporting, budgeting has a positive impact on the level of corporate governance (Uyar, 2017).

For academics, researchers suggested that research be carried out using independent variables of practice management accounting. Whereas is the lack of sample size, so it has not been able to generalize conclusions.

\section{REFERENCES}

Alp, A., \& Ustundag, S. (2009). Financial reporting transformation: the experience of Turkey. Critical Perspectives on Accounting, 20(5), 680-699. https://doi.org/10.1016/j.cpa.2007.12.005

Bollen, K. A. (1989). Structure Equation Model that are nonlinier in Latent Variable: a LeastSquares Estimator. In Structure Equations With Latent Variables (pp. 223-251).

BPR. (2010). Pedoman Akuntasi Bank Perkreditan Rakyat, 1-157.

Bushman, R. M., \& Smith, A. J. (2003). Transparency, financial accounting information, and corporate governance. FRBNY Economic Policy Review, 9(1), 65$87 . \quad$ https://doi.org/10.1016/S01654101(01)00027-1

Christopher, S., Guay, W. R., Joseph, P., Link, C., \& Armstrong, C. S. (2010). The Role of Information and Financial Reporting in Corporate Governance and Debt Contracting. Journal of Accounting \& Economics, 50(2), 179-234.

Corcoles, Y., Penalver, J., \& Ponce, A. (2011). Intellectual capital in Spanish Public Universities: Stakeholders ' Information Needs. Journal of Intellectual Capital, 12(3), 356-376. https://doi.org/10.1108/1469193111115468 9

Eng, L. L., \& Mak, Y. T. (2003). Corporate governance and voluntary disclosure. Journal of Accounting and Public Policy, 22, 325-345.

https://doi.org/10.1016/S02784254(03)00037-1

Fornell, C., \& Larcker, D. F. (1981). Evaluating Structural Equation Models with Unobservable Variables and Measurement Error. Journal of Marketing Research, 18(1), 39. https://doi.org/10.2307/3151312

Hair, J., Hult, T., Ringle, C., \& Sarstedt, M. (2014a). A Primer on Partial Least Squares Structural Equation Modeling (PLS-SEM). California: SAGE. https://doi.org/10.1007/978-3-319-71691-6

Hair, J., Hult, T., Ringle, C., \& Sarstedt, M. (2014b). Partial Least Squares Structural Equation Modeling ( PLS-SEM ). USA: SAGE Publication.

Haniffa, R. M., \& Cooke, T. E. (2002). Culture , Corporate Governance and Disclosure in Malaysian Corporations. A Journal of Accounting Finance and Business Studies, 38(3), 317-349. https://doi.org/https://doi.org/10.1111/14676281.00112

http://www.simulasikredit.com. (n.d.). Apa itu Standar Akuntasi Keuangan Apa Fungsi Standar Akuntansi Keuangan SimulasiKredit. 
Huynh, Q. L. (2015). The mutual relationship between corporate governance and management accounting: Which occurs first? American Journal of Applied Sciences, 12(6), 403-410. https://doi.org/10.3844/ajassp.2015.403.41 0

IAI. (2016). Standar Akuntansi Keuangan- IAI Global. Retrieved from http://iaiglobal.or.id/v03/standar-akuntansikeuangan/etap

International Finance Corporation. (2017). Corporate governance frequently asked questions.

Joshi, P. L., \& Ramadhan, S. (2002). The adoption of international accounting standards by small and closely held companies: Evidence from Bahrain. International Journal of Accounting, 37(4), 429-440. https://doi.org/10.1016/S00207063(02)00190-5

Martani, D. (2017). Penyajian Laporan Keuangan.

Mwangi, M. (2011). The Role of Budgeting in Promoting Corporate Governance on Constituency Development Funds Allocation: A Case of Nairobi Country (Vol. $55)$.

Nobes, C., \& Stadler, C. (2013). How arbitrary are international accounting classifications? Lessons from centuries of classifying in many disciplines, and experiments with IFRS data. Accounting, Organizations and Society, 38(8), 573-595. https://doi.org/10.1016/j.aos.2013.10.001

Pallisserry, F. (2016). True and Fair Financial Reporting: a tool for better Corporate Governance. Journal of Financial Crime, 19(4), 332-342. https://doi.org/Pallisserry, F. (2012). True and fair financial reporting: a tool for better corporate governance. Journal of Financial Crime, 19(4), 332-342. doi:10.1108/13590791211266331

Peraturan Nomor 4/POJK.03/2015 Tentang Penerapan Tata Kelola Bagi Bank Perkreditan Rakyat.
Seal, W. (2006). Management accounting and corporate governance: An institutional interpretation of the agency problem. Management Accounting Research, 17(4), 389-408.

https://doi.org/10.1016/j.mar.2006.05.001

Shil, N. C. (2008). Accounting for Good Corporate Governance, 3(1), 22-31. Retrieved from http://joaag.com/uploads/3_ShilFinal.pdf

Soleh, A. (2018). Kasus Penipuan Jadi Faktor Utama Penyebab Banyaknya BPR di Indonesia Tutup - TribunSolo. Retrieved from

http://solo.tribunnews.com/2018/02/22/kasuspenipuan-jadi-faktor-utama-penyebabbanyaknya-bpr-di-indonesia-tutup

https://ekonomi.kompas.com/read/2018/10/22/144 240026/hingga-semester-i-2018-bisnisbank-perkreditan-rakyat-masih-tumbuh

Tenenhaus, M., Amato, S., \& Vinzi, E. V. (2004). A global goodness-of-fit index for PLS structural equation modelling. The XLI/ SIS Scientific Meeting, 739-742.

Uyar, A. (2017). Impact of the Accounting Information System on Corporate Governance: Evidence from Turkish NonListed Companies Impact of the Accounting Information System on Corporate Governance: Australasian Accounting, Business and Finance Journal, 11(1), 9-27. https://doi.org/10.14453/aabfj.v11i1.3

Uyar, A., \& Güngörmüş, A. H. (2013). Perceptions and knowledge of accounting professionals on IFRS for SMEs: Evidence from Turkey. Research in Accounting Regulation, 25(1), 77-87. https://doi.org/10.1016/j.racreg.2012.11.00 1

Uyar, A., \& Kuzey, C. (2016). Contingent Factors, Extent of Budget Use and Performance: A Structural Equation Approach. Australian Accounting Review, 26(1), 91-106. https://doi.org/10.1111/auar.12090 